\title{
MANAGEMENT SYNERGIES: WATER RESOURCES AND FLOODING
}

\author{
MARIA-CARMEN VICENTE-TORRES, JOSÉ-SERGIO PALENCIA-JIMÉNEZ \& ERIC GIELEN \\ Universitat Politècnica de Vàlencia, Spain
}

\begin{abstract}
The fifth report of the European Commission, COM (2019) 95final, on the implementation of the Water Framework Directive (Second River Basin Management Plans 2000/60/EU and First Flood Risk Management Plans 2007/60/EU), in order to coordinate the authorities involved and exploit synergies, recommends that Spain considers flooding within the National Climate Change Adaptation Strategy. The operation of dams on the territory of the Community is proposed by Spain in the EU Guidance document No. 24 "River Basin Management in a Changing Climate" (TR-2009-040) as a measure of resilience to water scarcity, accentuated by climate change.

Optimal management of water resources in catchments and their surroundings ensures the different uses of water: ecological (protected areas and population supply), agricultural, industrial and recreational, as well as flood safety of people and property. Land use planning that includes areas of temporary flooding during high precipitations, run-off or overflow can contribute significantly to improve the operation of reservoirs.

In this article, we analyse the flood areas of different types of watersheds, based on real cases, defined by a variety of geo-morphologies downstream of the dam (channels, gullies and flat-bottomed troughs, flood plains) and by current anthropogenic uses occupying the territory. The results are analysed with reference to their potential for synergy with the operation of the upstream water reservoir. Key trends shown are proposed to be translated into coefficients of reduction in environmental and socioeconomic damages within the model of spillways simulation.

Keywords: catchment, controlled flood zones, dams operation, land uses, risks.
\end{abstract}

\section{INTRODUCTION}

World Circular Economy is related to well-being and sustainable development. The availability of water occurs to be the basis of every human settlement. In order to improve its use, in Spain, numerous dams have been built in the last century; a number of them are strategically located upstream of villages or cities. These traditionally grey structures can definitely change their role as part of the network of green structures while retaining and providing water following optimal routines.

The definition of these routines gets critical especially during floods. Heavy precipitation in a river basin varies according to random tendencies. Flood Control Dams were built as measurements of protection where downstream field crops, industries, cities and netroads suffered significant damages. In these cases, when precipitations overpass defined dam standards, catchments response is unpredictable.

Following the water policy of avoiding all human risks, engineers in charge of their operation, in communication with the catchment office in the River Basin Demarcation, try each humid period not to worsen the situation downstream from the natural scenario. Each humid event, Dams Standars in Spain (on process) are binding to reach a release flow greater than the uncertain maximum [1] arriving into the water surface of the reservoir a discharge through; while promoting a discharge the spillways [2] enough to ensure the structural stability of the dam.

Many of this flood protection dams share objectives with the human settlements they must protect. For example, hydropower energy production, drinking water potabilization, ecological flow, agricultural irrigation, etc. Therefore, their capacity had been designed to guarantee 
all of them. Multifunctional dams operation is a challenge for authorities in order to optimize water volume in reservoirs, and in consequence, sustainable development of their hydric basins, including ecological and socio-economic benefits. Multifunctional dams whose previous water surface level [3] need to be determinate with accuracy after high-precipitations prediction; resulting not only in hydraulic safety of the dam, but also in a sufficient final water surface level available for next dry period.

In this work, we pretend to establish criteria to support both dams operation in storms and flooding/retaining designed areas downstream as a binomial mechanism of floods control that permits environmental, economical and safety improvements in the basin. By analysing through four cases study, not only the influence of each dam-basin typology but also, the impact of taking actions: varying from traditional floods protection to proposed floods control tendence. Benefits for the operativity in dams and their catchments are pre-assessed by geomorphological and land use indicators.

\section{STATE OF THE ART}

The operation routines of the spillways in dams have been focussed, through current scientific literature, on the water current scientific literature, the water level in the reservoir, as the hydrological variable that summarizes all hydrology of a basin. Either by attempting to apply a given initial guard that permits optimizing the water balance in the storm [4], or by maintaining a water surface level above the desirable operating value [5]. The joint application of both criteria to specific cases has involved the development of models that gradually included dams release flow significance [6] and its downstream effects; even consideration of dams discharge as the determining factor in the formulation of the real-time operation gates model is still pending.

The flood wave is a non-stationary movement [7] because the speed, depth and occupancy of the water vary over time. In addition, the hydrological uncertainties associated with flow release do not allow predictions with enough precision and anticipation required in real time simulations. Despite of uncertainty, flood return periods [8] have been taken into account in discharge ranges at the spillway. Uncertainty is compounded by climate change consideration [9] in the precision, inter alia, of the flood quantile estimators.

Climate change is seen as one of the factors that increase disaster risk and has consequently accelerated the commitments made at the United Nations World Conference on 18 March 2015 by "Sendai Framework for Disaster Risk Reduction 2015-2030" [10]. These commitments are based mainly on "substantial reduction of disaster risk and disaster losses, both in lives, livelihoods and health, and in the economic, physical, social, cultural and environmental assets of individuals, businesses, communities and countries". To assist in the development of the actions to be adopted, guiding principles were defined, of which we highlight the investment in disaster risk reduction for resilience and increased disaster preparedness for effective response and for "better rebuilding" in the areas of recovery, rehabilitation and reconstruction. Within this framework, we understand that the location and adaptation of areas destined for controlled flooding that compensate for the increased risk of climate change takes place, reducing the risk on people and their property.

The assessment of the impacts of climate change implies a high uncertainty that leads to the development of adaptation strategies because of their considerable flexibility and effectiveness in reducing losses and damages, particularly in Europe [11]. In Spain, the transposition of Directive 2007/60/EC, of the European Parliament and of the Council of 23 October 2007 on flood risk assessment and management, into Spanish law through the adoption of Royal Decree 903/2010, on 9 July, in the field of flood risk assessment and management, marked 
a significant change in the way floods are understood and dealt with by the administrations directly linked to the occurrence of flooding, as well as the incorporation of new regulations and the application of uniform measures for action on flood-prone cities and municipalities throughout Spain, a situation which did not exist before, with the exception of basic State legislation [12].

The Ministry for the Ecological Transition and the Demographic Challenge (MITECO) has developed the Plan to Promote the Environment for Adaptation to Climate Change in Spain (PIMA Adapta), which runs from 2015 to 2020, and in which there are four strategic lines, among which we highlight the adaptation to extreme events and the assessment of the impact of climate change on water resources and the development of adaptation strategies. In this context, in 2018, the Government of Aragon drew up a document of urgent measures to reduce the risks of flooding in the Aragonese stretch of the Ebro, among which the creation of controlled flood areas and rolling measures in the floods plain itself was proposed [13].

\section{METHODOLOGY OF ANALYSIS}

Approaching flooding risk (according to Directive 2007/60/CE and its Spanish transposition R.D 903/2010) as result of three main factors: hazard, exposition and vulnerability (being hazard due to the confluence of susceptibility and frequency), an empiric method based on geomorphological and land use indicator is proposed in this article. The aim is to demonstrate the viability of increasing outflows range in the operation rules of the spillways, by the implementation of flooding risk mitigation measurements, natural [14] or anthropogenic [15] based; and consequently, accomplishing an adequate extreme peak flows lamination while decreasing hydric, hydrological and structural risks in dams catchments.

The downstream river geomorphology has been built by a dominant flow $\left(\mathrm{m}^{3} / \mathrm{s}\right)$ due to higher frequency. This frequency obtained from historic data must be definitely changing along, inter alia, the current climate change. If dominant flow implies high velocity, erosion of the bed river and sediment transport, floods should be to slightly higher velocities, upper water levels and sedimentation on the riversides; building embankments in a long term. In this work, no damaging water discharged in the spillways involves not only a full river section but also a volume $\left(\mathrm{m}^{3}\right)$ of flooding water over forest land and most of the agriculture land types.

Geographic Information Systems have been used for the selection of controlled flood areas in the pilot basins under study, allowing the combination of digital terrain models with land use information, such as the 2014 Spanish Land Use Information System, the danger of flooding for the 500-year return period, determined by the Júcar Hydrographic Confederation for the National System of Flood Zone Mapping of the first cycle (SNCZI), and urban planning, according to the information available at the Valencian Cartographic Institute.

The method calculates as indicator, in first static approach, the water volume (of reservoirs inputs T500) that after being discharged, it would be able to fill existing flooding plains by overtopping the river channel. Indicator values are calculated for several case studies by comparing two scenarios: the current scenario and the mitigation scenario where natural and anthropogenic measurements would have been implemented (land use changes, reforestation, contouring boundary lines channels, constructions demolition, retaining facilities, etc.) according to the hydric catchment geomorphology and territorial human occupancy.

In order to analyse indicator values homogeneously, four headwaters reservoirs have been selected from the Jucar River Demarcation: Amadorio, Beniarrés, Forata and El Regajo, located in a variety of hydric catchments in the Community of Valencia: Amadorio, Serpis, 
Magro and Palancia rivers under Mediterranean. Even though only one of the four study cases (Amadorio) is a remarked watershed pointed out by pre-assessed flooding risks Map (1st cycle of EU Directive), all four sites are susceptible of hazard. Therefore, they collaborate properly in the benefits assessment of the present methodology. Their analysis and discussion appear in the following paragraphs.

\section{ANALYSIS OF FOUR CASE STUDIES}

In this analysis, we are presenting four upper catchments in four rivers on the East coast of the Iberian Peninsula by their capacity [SNCZI-IPE]. The first case study corresponds to the Forata dam in the municipality of Yátova, Valencia province.

\subsection{Case study 1: Forata dam}

Watershed in the upper Magro River which flows into the Júcar River close to the town of Algemesí. The Júcar River ends in the municipality of Cullera (Valencia province). Following Forata dam pictures from latter field visit on 13 June, Figs. 1 and 2 show a reservoir for agriculture use in the early dry season; being filled almost $15 \mathrm{Hm}^{3}$ of the $23 \mathrm{Hm}^{3}$ net volume for irrigation. Contributions above $28 \mathrm{Hm}^{3}$ (annual average) from a hydrologic basin of 1,058 $\mathrm{km}^{2}$ are regulated/laminated by this gravity dam of $37 \mathrm{Hm}^{3}$ of capacity at normal maximum level (NMN), whose taintor spill-gate discharges $929 \mathrm{~m}^{3} / \mathrm{s}$.

Classified as type A according to its potential risk and designed for almost $1.334 \mathrm{~m}^{3} / \mathrm{s}$ flood peak discharge has an emergency plan approved in 2010. Downstream of the dam the danger of flooding was determined for different return periods for SNCZI, with the peak flow for the 500 -year return period of $1,192 \mathrm{~m}^{3} / \mathrm{s}$ in the section where the controlled flood zone is planned to be located, approximately $11.2 \mathrm{~km}$ from the dam, due to the mountainous relief on the stretch of bed between the dam and the planned area. No special environmental retaining measurements are considered, as a precaution against the existing zebra mussel alert in the reservoir since 2006.

\subsection{Case study 2: Beniarrés dam}

The second case study taken into consideration is another agriculture irrigation-oriented dam: Beniarrés, in the municipality of the same name (Alicante province). Headwater and only
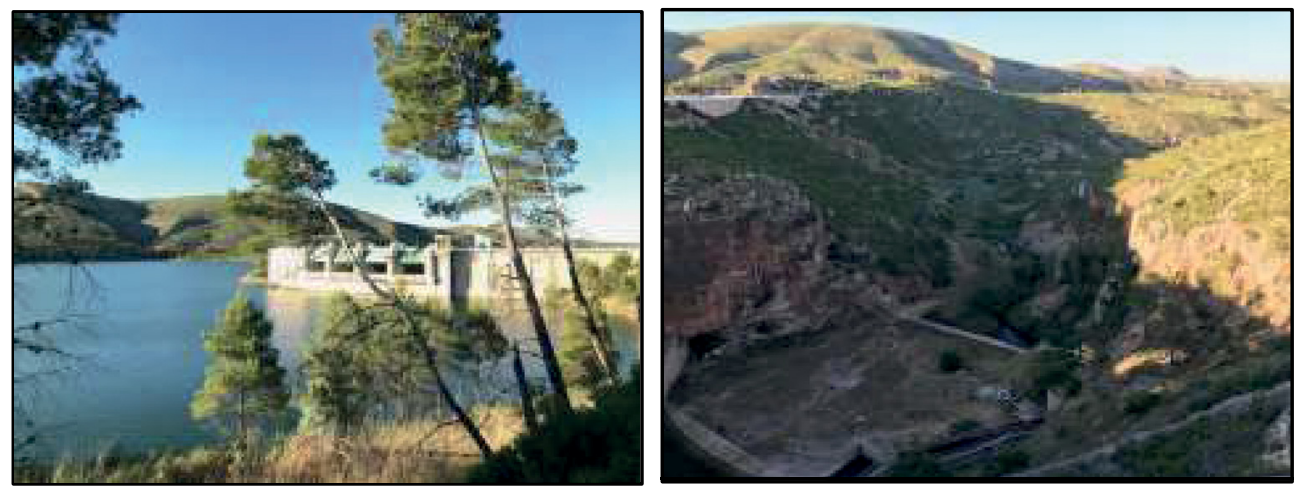

Figures 1 and 2: Forata state: $14.70 \mathrm{Hm}^{3}$ saih.chj.es. 


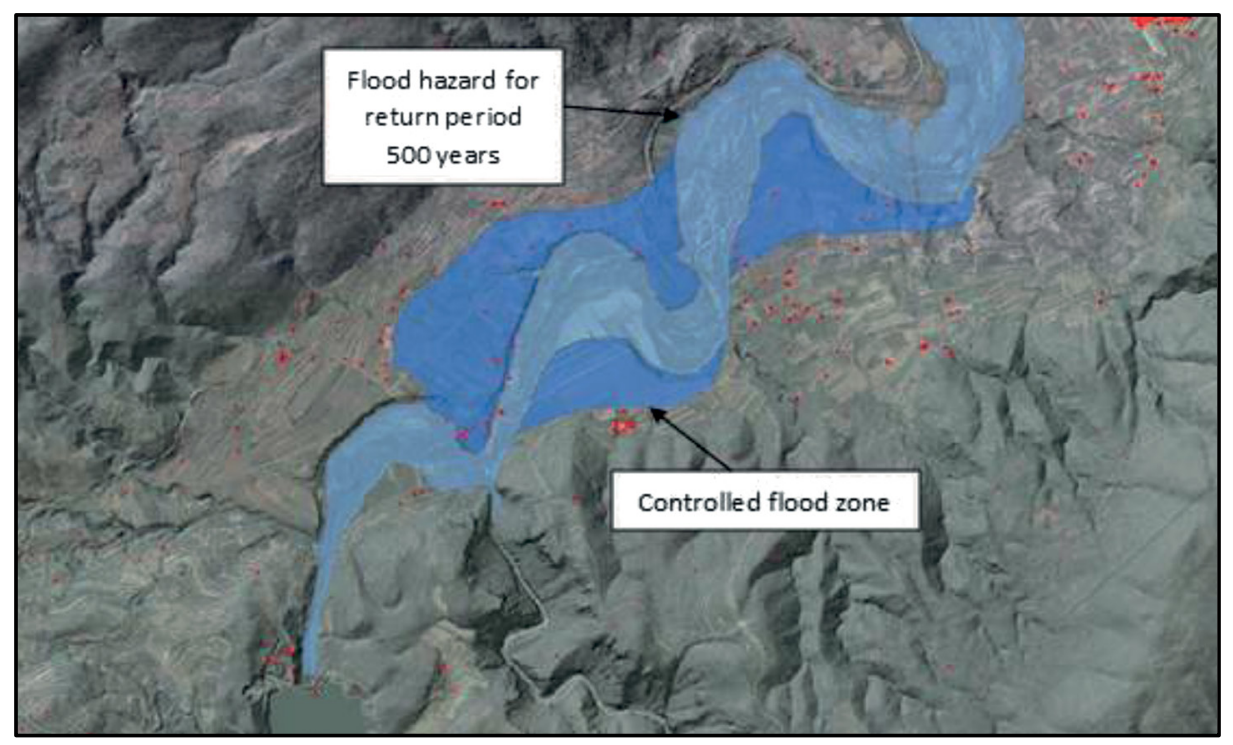

Figure 3: Control flood zone in the agricultural land use area - Beniarrés.

reservoir on the Serpis River which ends in Gandía town (Valencia province) at the Mediterranean Sea has a capacity of $27 \mathrm{Hm}^{3}$ at NMN. It was built (1958) as a gravity dam for equal project flood and spillway discharge of $1,000 \mathrm{~m}^{3} / \mathrm{s}$ by taintor gates. The hydrologic basin upstream is smaller than Forata basin, only $464 \mathrm{~km}^{2}$ of surface, but annual average contributions are higher, $83 \mathrm{Hm}^{3}$.

Classified as type A according to its potential risk assessment, corresponding emergency plan was approved in 2009. Downstream of the dam, the riverbed has several meanders with a morphology on the banks of terraces that constitute a valley mainly dedicated to agricultural uses. The flow rate determined for SNCZI and a return period of 500 years in this stretch is $1,691 \mathrm{~m}^{3} / \mathrm{s}$. The controlled flood zone proposed (Fig. 3) for analysis is located $1.6 \mathrm{~km}$ from the dam, in the agricultural valley area, and the municipality of L'Orxa is located at the end of the valley on the right bank of the river, so that it can benefit from rolling up in the controlled flood zone.

\subsection{Case study 3: Amadorio dam}

Our third case study, Amadorio dam on the river of the same name, was remarked as Area of Significant Potential Risk by the pre-assessed flooding risks Map (first cycle of EU Directive). A distance of only $4 \mathrm{~km}$ separates Amadorio reservoir from its mouth at Villajoyosa, Alicante province, at the Mediterranean Sea; being the shortest basin in Spanish territory.

No extra guard for floods lamination was included in the design of Amadorio dam, but the taintor spillway of $505 \mathrm{~m}^{3} / \mathrm{s}$ discharge capacity was bigger than adopted project flood peak of $400 \mathrm{~m}^{3} / \mathrm{s}$, allowing a volume at NMN about $16 \mathrm{Hm}^{3}$, practically the total $16.6 \mathrm{Hm}^{3}$. The hydrologic basin upstream has only a non-significant old dam featuring as a retaining infrastructure, annual precipitations on the $210 \mathrm{~km}^{2}$ mountain surface implies $5.5 \mathrm{Hm}^{3}$ of average inputs to regulate for agricultural and urban supplies by Amadorio dam. 


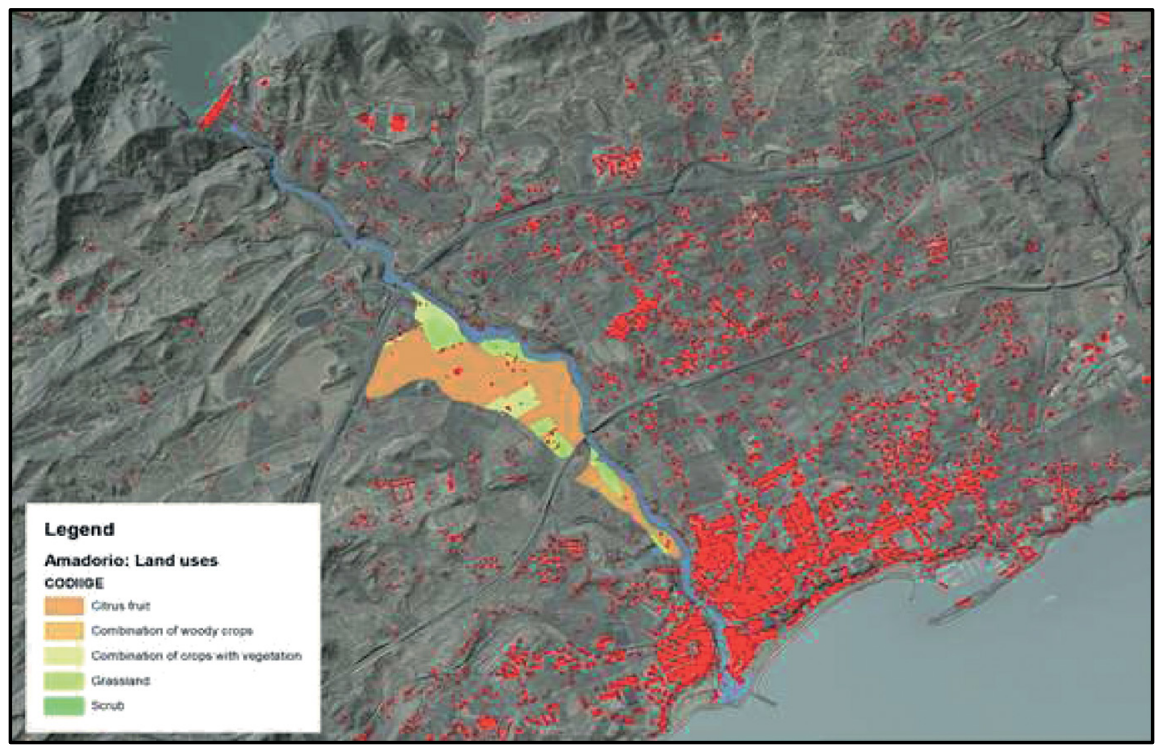

Figure 4: The municipality of Villajoyosa downstream Amadorio dam.

Classified as type A according to its potential risk assessment, corresponding emergency plan was approved in 2009. The peak flow considered for calculation of the flooding risk for a return period of 500 years by SNCZI was $504 \mathrm{~m}^{3} / \mathrm{s}$, practically the design discharge capacity through the spillway.

The short route of the channel between the dam and its mouth, and the presence of urban settlements in its final stretch, poses a high risk to the population due to the possible increase in flows due to climate change. Land on the right bank of the river between the AP7 motorway and the town centre of Villajoyosa is therefore proposed as a study area (Fig. 4) for controlled flooding. The existing uses in this area are those shown in the following picture, where agricultural uses and their combination with natural vegetation/pastures predominate.

\subsection{Case study 4: El Regajo dam}

El Regajo dam in the municipality of Jérica (Castellón province) is our last case study, designed for a project flood peak of $1,884 \mathrm{~m}^{3} / \mathrm{s}$. It is a gravity dam of $407 \mathrm{~m}$ coronation height and 405 normal maximum level whose taintor spill-gate discharges $400 \mathrm{~m}^{3} / \mathrm{s}$. Built in 1959 by Segorbe Irrigation Union and Sagunto "Sequia Major" Irrigation Community, it collects the contributions ( $82 \mathrm{Hm}^{3}$ annual average) of a $466 \mathrm{~km}^{2}$ hydrologic basin surface. The reservoir capacity, basically used for agricultural irrigation, has been restricted from a total volume of $7 \mathrm{Hm}^{3}$ to a maximum safe volume of $4.9 \mathrm{Hm}^{3}$ in dry periods, and $3 \mathrm{Hm}^{3}$ in humid periods, by authorities since last decade [16].

This headwater regulation scheme in the Palancia River, after a latter regulation through El Algar dam included in 2000, leads in the municipality of Sagunto (Valencia province) at the Mediterranean Sea. According to PGRI, 13 historic floods have been registered in lower part of the Palancia River, resulting up to $40 \mathrm{~km}$ on potential flooding risk 


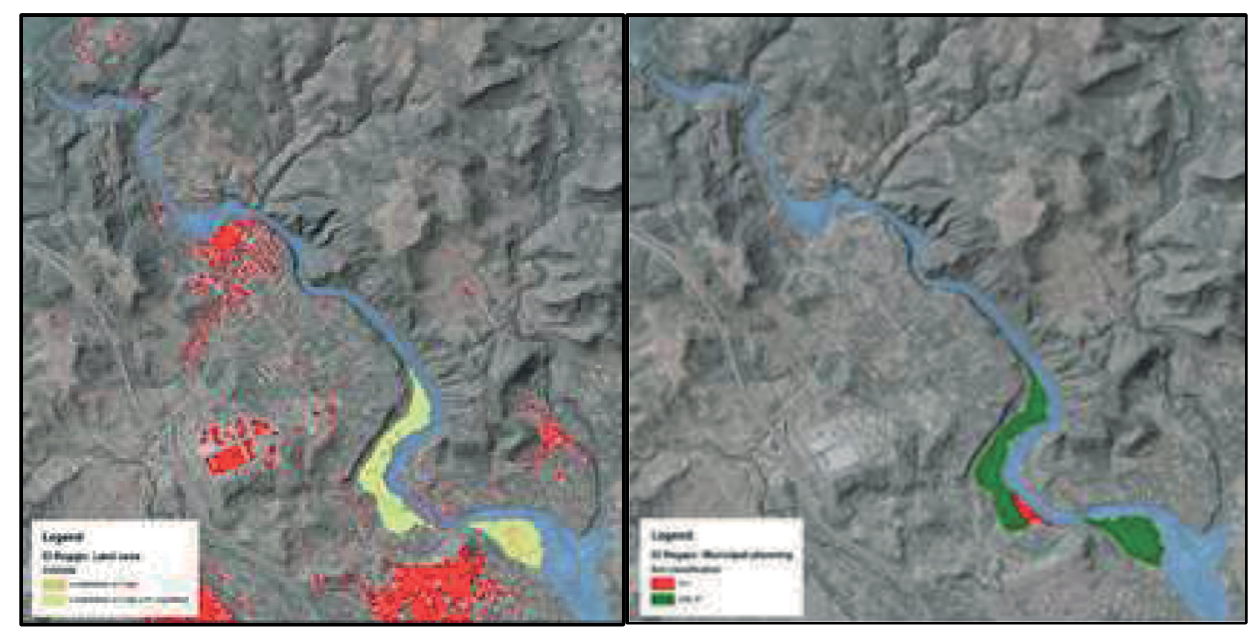

Figure 5 and 6: Proposed areas downstream El Regajo dam and upstream Algar dam.

(ES080_ARPS_0024_01/02/02/04. Palancia River - Sagunto and Almenara gullies). The steep morphology of the valley through which the River Palancia flows downstream of the El Regajo dam has not allowed us to locate terraces that can act as zones of controlled flooding up to $4.8 \mathrm{~km}$ downstream. Specifically, the proposed zone is located between the municipalities of Navajas and Segorbe. The peak flow considered for the 500-year flood return period by SNCZI in the stretch where the controlled flood zone is proposed is $2,057 \mathrm{~m}^{3} / \mathrm{s}$. Figures 5 and 6 show the proposed areas, as well as the land use, mainly a combination of crops and the classification of the soil according to municipal planning; noting the presence of an urban land area, which will be studied for further incorporation, presents currently a reduced spread of housing exempt from consolidate urbanization.

\section{DISCUSSION OF RESULTS}

The objective of locating controlled flood areas downstream of the selected dams is to improve the sequences of their discharges in extreme floods by combining both: the adequate operation of their spill-gates with the availability of areas (suitables or induced) where to be flooded according with a pre-established control program and consequently, minorating risks that are being definitely exacerbated by current changing climate.

For this purpose, areas have been pre-selected, such as those shown in the Fig. 7, whose surfaces and volumes of water were estimated in this first approach, as expressed in Table 1. Static indicators are defined by dimensional ratios of calculated volume and dam capacity in each case; El Regajo and Beniarrés are selected as more suitable of spill-gates operation optimization after a static indicator above $5 \%$, coinciding simultaneously with no lamination volume capacity.

Criteria dealing with new boundary conditions definition on dams operation routines in real time need to be developed in both frameworks: water resources and flooding. In this line, the classification of parameters which are involved in the present pre-selection method is pointed out: topography, land use and municipal planning. 
Table 1: First approach of static indicators in the four case studies.

\begin{tabular}{lllll}
\hline Controlled Flood & Dam & Surface $\left(\mathbf{m}^{2}\right)$ & Volume $\left(\mathbf{m}^{3}\right)$ & Static Indicator \\
\hline Palancia River & El Regajo & 371.112 & 556.668 & $8 \%$ \\
Magro River & Forata & 1.159 .361 & 1.739 .042 & $5 \%$ \\
Serpis River & Beniarrés & 1.186 .572 & 1.779 .858 & $6 \%$ \\
Amadorio River & Amadorio & 556.453 & 834.680 & $5 \%$ \\
\hline
\end{tabular}
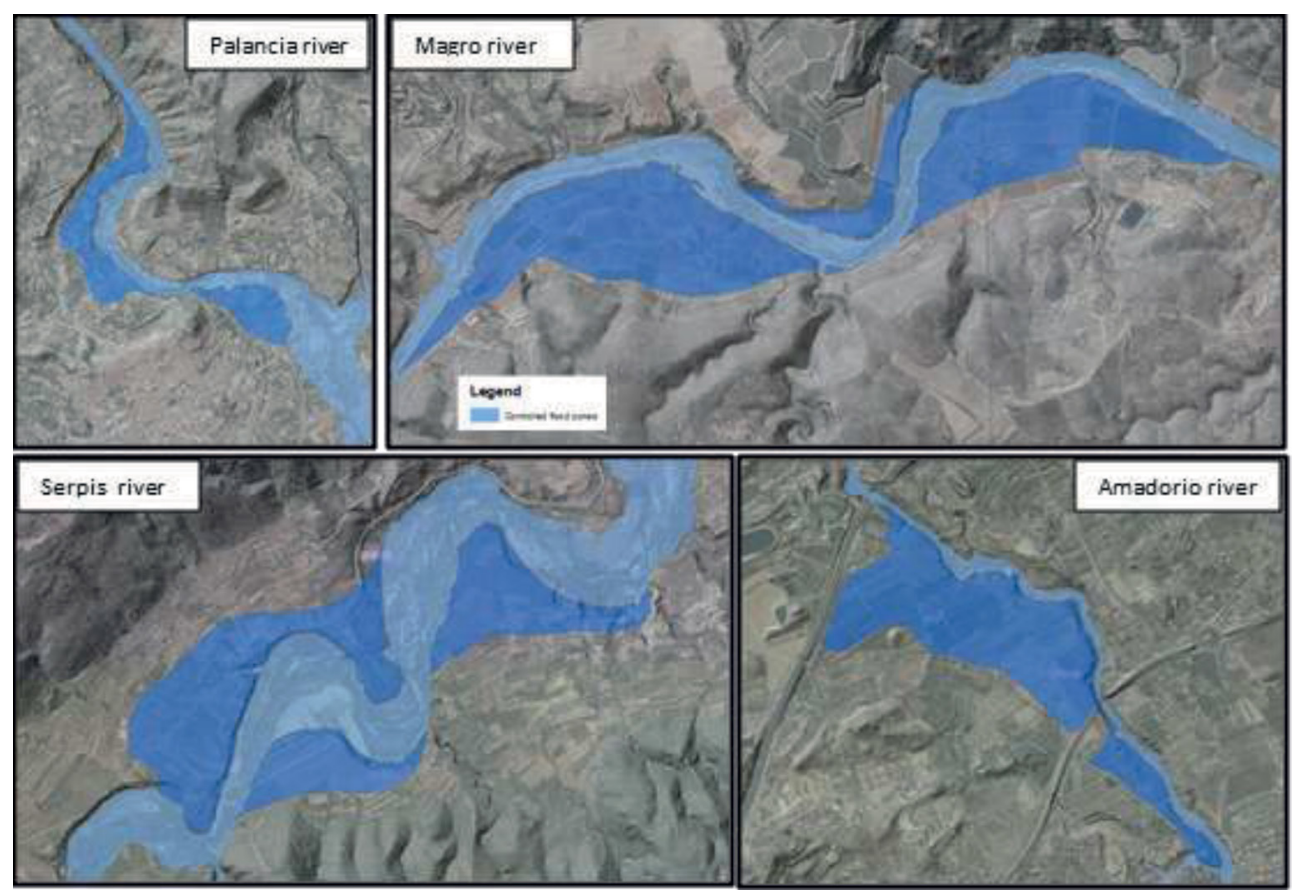

Figure 7: Pre-selected areas in four reservoirs from rural to urban areas.

The topography of the areas corresponds mainly to terraces located in their upstream areas near the height of the flood of 500 years of return period, in order to be able to derive and laminate the flood.

In all cases, predominant land uses are agricultural, forestry or a combination of both (Tables 2, 3, 4 and 5). The biggest problem encountered in all cases is the presence of scattered housing which will need to be the subject of a more thorough analysis to determine its maintenance and acquisition.

Municipal planning forecasts have been taken into account in the municipalities where the controlled flood zones have been proposed. Majority flood control zones would be located on undeveloped land down diverse protection. For example, in the river Palancia affectations were found, and they should be studied in detail. Another example, in the last stretch of the 
Table 2: Land use and land classification - Forata.

\begin{tabular}{llll}
\hline Magro River - Forata Dam & \multicolumn{3}{c}{ Soil Classification } \\
\hline Land Uses & SNU-C $\left(\mathbf{m}^{2}\right)$ & SNU-P $\left(\mathbf{m}^{2}\right)$ & Total $\left(\mathbf{m}^{2}\right)$ \\
\hline Combination of crops & 50.939 & 42.019 & 92.958 \\
Combination of crops with vegetation & 43.024 & 490.093 & 533.117 \\
Combination of woody crops & 26.192 & 84.675 & 110.867 \\
Herbaceous crop & 30.594 & & 30.594 \\
Citrus fruit & 119.377 & 51.702 & 171.079 \\
Non-citrus fruit & 38.893 & 35.252 & 74.145 \\
Industrial & & 20.063 & 20.063 \\
Scrub & 2.716 & 20.417 & 23.133 \\
Grassland & & 33.784 & 33.784 \\
Soil without vegetation & 35.457 & 34.166 & 69.623 \\
Total & 347.191 & 812.170 & 1.159 .361 \\
\hline
\end{tabular}

Table 3: Land use and land classification - Amadorio.

\begin{tabular}{lllll}
\hline Amadorio River - Amadorio Dam & \multicolumn{4}{c}{ Soil Classification } \\
\hline Land Uses & SNU-C $\left(\mathbf{m}^{2}\right)$ & SNU-P $\left(\mathbf{m}^{2}\right)$ & $\mathbf{S U Z}\left(\mathbf{m}^{2}\right)$ & Total $\left(\mathbf{m}^{2}\right)$ \\
\hline $\begin{array}{l}\text { Combination of crops with } \\
\text { vegetation }\end{array}$ & 48.542 & 6.290 & & 54.832 \\
Combination of woody crops & 13.421 & & & 13.421 \\
Citrus fruit & 350.518 & 22.587 & 18.757 & 391.861 \\
Scrub & 244 & 3.057 & 1.675 & 4.975 \\
Grassland & 71.336 & 16.173 & 3.298 & 90.808 \\
Road or rail network & 7 & 214 & & 222 \\
Soil without vegetation & 334 & & & 334 \\
Total & 484.401 & 48.322 & 23.730 & 556.453 \\
\hline
\end{tabular}

Amadorio River, a newly developed residential land would be affected; being not ordered or occupied by buildings, a green infrastructure within the urban sector could be developed.

Results allow to conclude that optimal definition of gate opening routines in dams based on programmed release flow, either in the weeks prior to storms or during them, would allow "placing" useful volumes of water in a variety of catchments typology; increasing the available volume in reservoirs for floods lamination and, therefore, amplifying the decision range of spillway operation. Dynamic indicators definition is still pending for further research. 
Table 4: Land use and land classification - Beniarrés.

\begin{tabular}{lll}
\hline Serpis River - Beniarrés Dam & & Soil Classification \\
\hline Land Uses & SNU-P $\left(\mathbf{m}^{2}\right)$ & Total $\left(\mathbf{m}^{2}\right)$ \\
\hline Coniferous forest & 7 & 7 \\
Combination of crops & 155.976 & 155.976 \\
Combination of crops with vegetation & 98.933 & 98.933 \\
Combination of woody crops & 113.286 & 113.286 \\
Vegetation combination & 8.664 & 8.664 \\
Herbaceous crop & 348.895 & 348.895 \\
Non-citrus fruit & 49.817 & 49.817 \\
Scrub & 124.997 & 124.997 \\
Olivar & 28.059 & 28.059 \\
Grassland & 235.527 & 235.527 \\
Road or rail network & 22.413 & 22.413 \\
Total & 1.186 .572 & 1.186 .572 \\
\hline
\end{tabular}

Table 5: Land use and land classification - El Regajo.

\begin{tabular}{llll}
\hline Palancia River - El Regajo Dam & \multicolumn{3}{c}{ Soil Classification } \\
\hline Land Uses & SNU-P $\left(\mathbf{m}^{2}\right)$ & $\mathbf{S U}\left(\mathbf{m}^{2}\right)$ & Total $\left(\mathbf{m}^{2}\right)$ \\
\hline Leafy forest & 4.046 & 462 & 4.508 \\
Combination of crops & 40.105 & & 40.105 \\
Combination of crops with vegetation & 304.447 & 22.047 & 326.494 \\
Road or rail network & 4 & & 4 \\
Total & 348.603 & 22.509 & 371.112 \\
\hline
\end{tabular}

\section{REFERENCES}

[1] Zhang, Y., S.M. ASCE; Singh, V.P., Dist.M. ASCE; y M. ASCE. (2019) "Método de escala de cuenca para precipitación máxima probable con análisis de incertidumbre". Revista Ingeniería Hidrológica. 24 (2); 04018067.

[2] Afsar, A. y Mariño, miembro de M.A. ASCE. (1990) “Optimización de la capacidad del vertedero con incertidumbre en el estimador de inundación”. Journal Water Resources Planning and Management 116 (1): 71-84.

[3] Carvajal, C., Peyras, L., Amaud, P., Boissier, D. y Royet, P. (2009). "Modelado probabilístico del nivel de agua de inundación para embalses de presas". Revista Ingeniería Hidrológica. 14 (3): 223-232.

[4] Girón, F., (1988). "La evacuación de las inundaciones durante la operación de los embalses". Transacción Decimosexto Congreso Internacional sobre Grandes Presas, 13-16 de junio, San Francisco, EE. UU., 1261-1263. 
[5] Villard, J. F. Les consignes de crues. La formación continúa B.E.T.C.G.B. Lyon, Francia. 17-20 de marzo de 2014.

[6] Sordo-Ward, A., Gabriel Martín, I., Bianucci, P. y Garrote, L. (2017) "Un método paramétrico de control de inundaciones para presas con aliviaderos controlados por puertas". Agua 9, 237; DOI: 10.3390 / w9040237'.

[7] Teixeira, L. "Propagación de crecidas". (2010) Programa de Formación iberoamericano en materia de aguas. Montevideo, Uruguay.

[8] Acanal, N., Haktanir, T. (1999). "Enrutamiento de inundaciones en cinco etapas para embalses cerrados al agrupar las inundaciones en cinco categorías diferentes de acuerdo con sus períodos de retorno". Revista de Ciencias de Ciencias Hidrológicas. 44 (2), 163-172.

[9] Stedinger, J.R. (2012) "Métodos estadísticos para evaluar el riesgo de inundación y el desafío del cambio climático". Revista de Ingeniería n. 36. ISSN 0121-4993.

[10] NACIONES UNIDAS (2015). "Marco de Sendai para la Reducción del Riesgo de Desastres,2015-2030". https://www.unisdr.org/files/43291_spanishsendaiframeworkfordisasterri.pdf

[11] Zbigniew W. Kundzewicz (2002). "Non-structural Flood Protection and Sustainability”, Water International, 27:1, 3-13, DOI: 10.1080/02508060208686972

[12] Palencia Jiménez, J.S. (2017) "Resiliencia territorial ante catástrofes. Inundaciones y temporales". Revista de Obras Públicas n. 3591, 30-39. ISSN 0034-8619.

[13] Gobierno de Aragón (2018). Medidas urgentes para reducir los riesgos por inundación en el tramo aragonés de la ribera del Ebro.

[14] Tara, A., Ninsalam, Y., Tarakemeh, N. y Muni, V. (2020). "Diseño con soluciones basadas en la naturaleza para mitigar las inundaciones en la cuenca del río Mataniko, Honiara". Journal on Landscape Architecture (5): 457-466. DOI: 10.14627 / 537690047.

[15] Bussi, G., Ortiz, E., Francés, F., Pujol, L., Gabaldón, R., Guna, V., Bellver, V., Sempere, J.A. (2011). "Modelación hidráulica y análisis del riesgo de inundación según las líneas guía de la Directiva Marco del Agua. El caso de la Marina Alta y la Marina Baja (Alicante)". Congreso DIHMA-UPV.

[16] https://www.acequiamayordesagunto.com/index.php/infraestructuras/pantano-de-regajo 